\title{
Emerging SARS-CoV-2 Genetic Variations and Mutations in the COVID-19 genomic sequence: A Systematic and Meta-analysis review
}

\section{Reza Valadan}

Department of Immunology, Faculty of Medicine, Mazandaran University of Medical Sciences, Sari, Iran

\section{Reza Alizadeh-Navaei}

3- Gastrointestinal Cancer Research Center, Mazandaran University of Medical Sciences, Sari, Iran

Monireh Golpour

4- Molecular and Cell Biology Research Center, Faculty of Medicine, Mazandaran University of Medical Sciences, Sari, Iran

Mehrdad Gholami

5- Department of Microbiology and Virology, Faculty of Medicine, Mazandaran University of Medical Sciences, Sari, Iran.

\section{Mehryar Zargari}

6- Department of biochemistry and genetic, Molecular and cell biology research center, Faculty of Medicine, Mazandaran University of medical sciences, Sari, Iran

\section{Mohammadreza Haghshenas}

7- Department of Microbiology, Molecular and Cell-Biology Research Center, Faculty of Medicine, Mazandaran, University of Medical Sciences, Sari, Iran

Tahoora Mousavi ( $\nabla$ stm.jmums@gmail.com )

8- Molecular and Cell Biology Research Center, Hemoglobinopathy Research Institute, Mazandaran University of Medical Sciences, Sari, Iran

\section{Systematic Review}

Keywords: SARS-CoV-2, Genetic Variation, Mutation, COVID-19 sequences

Posted Date: March 9th, 2021

DOI: https://doi.org/10.21203/rs.3.rs-307547/v1

License: () (i) This work is licensed under a Creative Commons Attribution 4.0 International License. Read Full License 


\section{Abstract}

\section{Objectives}

Severe acute respiratory syndrome coronavirus 2 (SARS-CoV-2) is the causative agent of coronavirus disease 2019 (COVID-19). The high mutation rate of RNA viruses causes genetic variation, virus evolution and it is a strategy to escape the immune system. In the present study, all researches and evidence were extracted from the available online national databases. Two researchers randomly evaluated the assessment of the research sensitivity. Finally, after quality assessment and specific inclusion and exclusion criteria, the eligible articles were entered for meta-analysis. The heterogeneity between the results of studies was measured using test statistic (Cochran's Q) and $\mathrm{I}^{2}$ index. The forest plots illustrated the point and pooled estimates with $95 \%$ confidence intervals (crossed lines). All statistical analyses were performed using Comprehensive meta-Analysis V.2 software.This meta-analysis included 13 primary studies investigating the SARS-CoV-2 genetic variations and mutations in the COVID-19 genomic sequence. According to the pooled prevalence ( $95 \%$ confidence interval) of mutations, the spike gene variations showed the highest nonsynonymous mutation frequency $(16.4 \%, \mathrm{Cl}: 13.6,16.6)$ and the Non-structural protein (NSP) genes possess the highest mutation frequency among total mutations (31.6\%, Cl: $21,44.6)$. Genomic mutation analysis of SARS-CoV-2 strains may provide knowledge about different biological infrequent mutations and their relationships of viral transmission, pathogenicity, infectivity, and fatality rates between SARS-CoV-2 and human cells.

\section{Introduction}

Severe acute respiratory syndrome coronavirus 2 (SARS-CoV-2) the causative agent of coronavirus disease 2019 (COVID-19), poses a foremost challenge to public health. Since the primary appearance of SARS-CoV-2 in late December 2019 in Wuhan, Hubei province, central China, a high dissemination rate has been observed worldwide [1]. Based on information released from the World Health Organization (WHO) on 29 December 2020, the present pandemic COVID-19 has nearly 79 million confirmed cases worldwide and over 1.7 million [2]. The SARS-CoV-2 is classified in the family of Coronaviridae, the order of Nidovirales, and the genus Betacoronavirus [3]. Similar to other coronaviruses, the genome of SARS-CoV-2 consists of specific genes encoding some structural/non-structural proteins [4]. Mutation level among RNA viruses is notably high, which this phenomenon is essential for

viral adaptation [5]. Though, coronaviruses have been introduced to have proofreading systems and so, nucleotide sequence variety in SARS-CoV-2 has been observed at a very low level [6]. In a study, Wang et al. reported the presence of 13 variations site in openreading frames (ORF) of SARS-CoV-2 [in 1a, 1b, S, 3a, M, 8] and N regions, which among them positions nt28144 and nt8782 in ORF 8 and ORF 1 a indicated mutation rate of $30.53 \%$ and $29.47 \%$, respectively [7]. In addition, based on the evidence obtained from a study on 48,635 SARS-CoV-2 sequences, 353,341 mutations have been detected throughout the world. Among them, D614G mutation in C-terminal of the spike protein (Aspartate to Glycine substitution at position 614) is one such evolutionary alteration detected in the SARS-CoV-2 and has become the most common type reported in many regions of the world such as Europe, Oceania, South America and Africa [8]- [9]. The present study was aims to assess the prevalence of SARS-CoV-2 genetic variation and mutation in COVID-19 sequences.

\section{Genetic diversity and mutations of the COVID-19}

There are several reports of unusual public health due to variants of SARS-CoV-2, which changes in transmissibility, clinical features, and severity. Table 1 shows the list of significant mutations in the world.

Table 1: The list of significant mutations in the world. 


\begin{tabular}{|c|c|c|c|c|c|}
\hline References & Out comes & Location & Area & $\begin{array}{l}\text { Time of } \\
\text { mutation }\end{array}$ & $\begin{array}{l}\text { Name of } \\
\text { Variant or } \\
\text { mutation }\end{array}$ \\
\hline [10], [11] & $\begin{array}{l}\text { - D614G have indicates greater transmissibility in } \\
\text { humans rather than greater pathogenicity. } \\
\text {-D614G produce higher viral loads. } \\
\text { - D614G variant more susceptible to neutralizing } \\
\text { antibodies and does not causes serious disease or } \\
\text { alter the efficacy of vaccines. }\end{array}$ & $\begin{array}{l}\text { spike } \\
\text { protein }\end{array}$ & China & $\begin{array}{l}\text { early } \\
\text { February } \\
2020\end{array}$ & D614G \\
\hline [12], [13] & $\begin{array}{l}\text {-Increased transmissibility } \\
\text {-No change in disease severity. } \\
\text {-No evidence that this variant has any impact on the } \\
\text { vaccine. } \\
\text { - Mutation of N501Y is detected in B.1.1.7. }\end{array}$ & RBD & $\begin{array}{l}\text { UK and } 31 \\
\text { other } \\
\text { countries }\end{array}$ & $\begin{array}{l}\text { December } \\
2020\end{array}$ & $\begin{array}{l}\text { SARS-CoV-2 } \\
\text { VOC } \\
202012 / 01 \\
\text { or } \\
\text { B.1.1.7 or } \\
20 B / 501 Y . V 1\end{array}$ \\
\hline [14] & $\begin{array}{l}\text {-Higher viral load } \\
\text {-Increased transmissibility } \\
\text { - No associated with more severe disease or worse } \\
\text { outcomes. } \\
\text { - K417N mutation effect on monoclonal and poly } \\
\text { clonal antibody. } \\
\text { - Mutation of N501Y, E484K and K417N are detected } \\
\text { in B.1.351. } \\
\text {-E484K makes the vaccine less effective against it. }\end{array}$ & RBD & $\begin{array}{l}\text { other } \\
\text { countries }\end{array}$ & $\begin{array}{l}18 \\
\text { December, } \\
2020 \\
30 \\
\text { December, } \\
2020\end{array}$ & $\begin{array}{l}\text { B.1.351 or } \\
501 Y . V 2\end{array}$ \\
\hline [15], [16] & $\begin{array}{l}\text { - This variant contain N501Y (More transmission) } \\
\text { and E484K (Escape of antibody) and K417N. } \\
\text { - Effective on the production of antibody, vaccination } \\
\text { or virus neutralization. }\end{array}$ & RBD & $\begin{array}{l}\text { Tokyo and } 3 \\
\text { other } \\
\text { countries } \\
\text { (Brazilian) }\end{array}$ & $\begin{array}{l}\text { January } \\
2021\end{array}$ & $\begin{array}{l}\text { B.1.1.248 } \\
\text { (P.1) or } \\
501 Y . V 3\end{array}$ \\
\hline [17] & $\begin{array}{l}\text { - Escape from immune system. } \\
\text { - SARS-CoV-2 Bind to Human ACE2 more strongly } \\
\text { than original strain. } \\
\text { - N439K escape from polyclonal and neutralizing } \\
\text { antibody responses. }\end{array}$ & RBD & $\begin{array}{l}\text { Wuhan, } \\
\text { Europe } \\
12 \text { countries }\end{array}$ & $\begin{array}{l}\text { March } \\
2020 \\
\text { October } \\
2020\end{array}$ & N439K \\
\hline [18] & $\begin{array}{l}\text {-It is not clear for increasing of the transmissibility of } \\
\text { the virus. } \\
\text {-Mutation of A222V and A220V are detected in } \\
\text { A.EU1. } \\
\text { - Spike mutations A222V had a functional effect on } \\
\text { spike's ability to mediate cell entry. } \\
\text { - Less effective against vaccine. }\end{array}$ & $\begin{array}{l}\text { spike } \\
\text { protein }\end{array}$ & $\begin{array}{l}\text { Spain, } \\
\text { UK } \\
\text { and } 12 \\
\text { countries }\end{array}$ & June 2020 & A.EU1 \\
\hline [19] & $\begin{array}{l}\text {-Decrease the duration of immune protection } \\
\text { following natural infection or vaccination } \\
\text { - Cluster } 5 \text { variant identified only in } 12 \text { human } \\
\text { casesand this variant dose not spread widely } \\
\text {-Might effect on vaccine development. }\end{array}$ & $\begin{array}{l}\text { spike } \\
\text { protein }\end{array}$ & Denmark & $\begin{array}{l}\text { August } \\
\text { and } \\
\text { September } \\
2020\end{array}$ & Cluster 5 \\
\hline
\end{tabular}

RBD: (Receptor-Binding Domain) 


\section{Methods}

\section{Search strategy}

In the present study, the search strategy was done using available online national databases, including ISI, Science direct, Scopus, Pubmed, Wiley and Google scholar between December 2019 and January 2020. The search was performed based on appropriate keywords of SARS-CoV-2, Variation, Mutation and COVID-19 sequences, which were combined with and/or/not to determine and screen articles in the search strategy. Besides, it is investigated the references of the published studies to improve the sensitivity of the search. The assessment of the research was randomly evaluated by two researchers and confirmed that all suitable studies had been detected.

\section{Study selection}

At first, articles of all researches, evidence or reports were extracted from the electronic database. After examinations of studies, duplicate articles were identified and removed from the study. Then, after analyzing the articles, the irrelevant articles were excluded by reviewing of title, abstract, and full text. Also, articles screened for eligibility and review articles and articles published in other languages were extracted from this study.

\section{Quality assessment}

The PRISMA checklist was used for evaluation of the quality of the related studies and determination of the selected studies based on title and contents. The PRISMA checklist consists of 27 items covering different aspects of research methodology such as determining Protocol and registration, eligibility criteria, search, study selection, defining variables, method of data collection, risk of bias in individual studies, presentation of results and statistical tests. Each question was required one score.

\section{Inclusion/exclusion criteria}

All articles approved by the above assessment phases were considered eligible for final meta-analysis: 1) All English studies. 2) Studies based on the prevalence of SARS-CoV-2 genetic variation among total mutation. 3) Reported prevalence of SARS-CoV-2 genetic variation among non-synonymous mutation. The following studies were ruled out: 1) Duplicated studies. 2) Non-relevant articles. 3) Article with non-full length sequence. 4) Abstracts, letters or review studies. 5) Studies published in languages other than English. 6) Articles with no access to the full-text.

\section{Data extraction}

After selection of appropriate articles, the following data for each research were extracted based on first author's name, geographical regions, publication year, language, the number of total mutations, non-synonym mutations, Mutation in $S$ protein, Mutation in N protein, Mutation in M protein, Mutation in E protein, ORF 1a/1b, ORF 3a, ORF 7a, ORF 7b, ORF8a, ORF 10a, ORF6, ORF 1a and NSP. The data were extracted and entered into a Microsoft Excel spreadsheet.

\section{Statistical analysis}

The primary outcome was the SARS-CoV-2 genetic variation and mutation in COVID-19 sequences. In our research, the heterogeneity between the results of studies was measured using the test statistic (Cochran's Q) and the $\mathrm{I}^{2}$ index. P-value less than 0.1 was used to consider significant heterogeneity.

The forest plots illustrated the point and pooled estimates with 95\% confidence intervals (crossed lines). Each box in a forest plot indicated the study's weight. The heterogeneity and homogeneity of the suspected factors were performed using random and fixed effects models, respectively and more than $50 \%$ were considered as high degrees of heterogeneity. All statistical analyses were performed using Comprehensive Meta Analysis V.2 software.

\section{Results}


In the present study, 1370 articles were identified in the starting process. The number of studies was reduced to 1209 following the removal of duplicate articles. In the next step, 890 irrelevant documents were removed after reviewing the full texts. Then, 319 articles were considered for further screening. After the exclusion of 291 articles, 28 articles were assessed for eligibility. 6 articles with non-full length sequence, 8 review articles and one article with other languages were excluded. Finally, 13 relevant articles were included in the Meta-analysis review (Fig.1). In addition, the geographic distribution and frequently mutated residues among COVID19 sequences are shown in table 2 and fig. 2 respectively.

\section{Analysis of mutationsamong non-synonymous mutation}

In the current study, the prevalence of S, N, M, E, ORF 1a/1b, ORF 3a, ORF 7a, ORF 7b, ORF 8a, ORF 10a and ORF 6 mutations among non-synonymous mutation is varied from $0.06 \%$ (ORF7b) to $70.44 \%$ (ORF 1a/1b) (Table 2, A). Also, it is shown that the highest and lowest frequency of S, N, M, ORF 3a, ORF 7a, ORF 7b and NSP mutations among total mutation belongs to N $(0.07 \%)$ and NSP $(44.14 \%)$ respectively (Table $2, \mathrm{~B})$.

In this review 8 sectional studies, S, N, M, E, ORF 1a/1b, ORF 3a, ORF 7a, ORF 7b, ORF 8a, ORF 10a and ORF 6 mutations were assessed among non-synonymous mutation.

\section{1 - Analysis of S mutation}

Our analysis revealed that the D614G spike mutation has the highest frequency. This mutation improved spike protein fitness with cell surface receptors and increased the virus's transduction compared to the wild type [20]. Other S mutations, P1263L, V483A, and L54F, have a low frequency. The forest plot shows that the overall frequency of $S$ mutation is $16.4 \%(13.6,16.6)$ and with the compounding of the results, the overall prevalence of $S$ mutation with the confidence interval of $95 \%$ and based on random effect model is $\left(1^{2}: 85.98 \%, Q=49.947, P<0.001\right)$. Also, the results of the heterogeneity studies show that there is heterogeneity among the primary results of the studies (Fig 3, A).

\section{2 - Analysis of $\mathrm{N}$ mutation}

Other frequent mutations are R203K and G204R located in the $\mathrm{N}$-area. $\mathrm{N}$ genes encode the nucleocapsid protein that contributes to the formation of helical ribonucleoproteins in the virus [21]. These mutations modify miRNAs' binding mechanism and changed the pathogenesis and development of COVID-19 infection in subjects [22]. Other mutations in region N include S197L, P13L, L37F, P323L, and P1103L, which are less frequent, respectively. As can be seen the total prevalence of N, mutations are estimated as $11.7 \%(7,19.1)$. Generally, with the compounding of the results, the overall prevalence of $\mathrm{N}$ mutation with the confidence interval of $95 \%$ based on the random effect model is $\left(I^{2}: 98.23 \%, Q=396.15, P<0.001\right)$. Besides, the results of the heterogeneity studies show that there is a heterogeneity among the initial results of the studies (Fig 3, B).

\section{3 - Analysis of M mutation}

The $\mathrm{M}$ protein plays a part in the viral envelope packaging by interacting with the $\mathrm{S}$ protein [23]. Our analysis revealed two lowfrequent T175M and D3G mutations in the M gene. Accordingly, analysis of M mutation is calculated $1.9 \%(0.9,4.1)$. The overall prevalence of $\mathrm{M}$ mutation with the confidence interval of $95 \%$ based on the random effect model is $\left(I^{2}: 84.70 \%, Q=45.76, P<0.001\right)$. The results of the heterogeneity studies describe that there is a heterogeneity among the result of these studies (Fig 3, C).

\section{4 - Analysis of ORF1a/1b mutation}

ORF1ab is a large gene that coded polyprotein (16 proteins) involved in virus genome synthesis and replication [24]. P4715L, L3606F, C8517T, A876T and F3071Y mutations are more frequent in ORF1ab. Due to the overall distribution of ORF 1a/1b mutation $12.8 \%(5.7,26.4)$ with the confidence interval of $95 \%$ based on random effect model is $(12: 97.09 \%, Q=240.66, P<0.001)$ and it is shown that there is a heterogeneity among the results of the studies (Fig 3, D).

\section{5 - Analysis of ORF3a mutation}

Q57H, G251V, S193I, and G196V are more frequent mutations in ORF3a. ORF3a proteins are located in host cells and found in the endoplasmic reticulum or Golgi intermediate space, acting as ion channels and controlling the virus's release [25]. moreover, ORF3a 
triggers pro-inflammatory pathways and assists in severing modes of infection [26]. It is noteworthy that the ORF3a gene shows a high level of non-synonymous and neutral mutations with a potential effect on B-cells like epitope generation that is a significant point [27]

The incidence of non-synonymous mutation according to ORF 3a group by $95 \%$ confidence interval in different studies is shown in the forest plot $5.7 \%(4.3,7.6)$. The results of the analysis demonstrated that the heterogeneity among reported studies is $(P<0.001$; $\mathrm{I}^{2}=78.67 \%, \mathrm{Q}=32.81$ ) (Fig 3.E).

\section{6 - Analysis of ORF7a mutation}

Test results of forest plot shows that the average rate of ORF $7 \mathrm{a}$ is reported to be $2.1 \%(1.3,3.3)$ and the overall prevalence of ORF 7a mutation with the confidence interval of $95 \%$ is $\left(1^{2}: 60.03 \%, Q=17.51, P=<0.014\right)$ So, there is aheterogeneity among these studies (Fig 3, F).

\section{7 - Analysis of ORF7b mutation}

The forest plot shows the prevalence of the non-synonymous mutation based on ORF 7b mutation and confidence intervals ( $95 \%$ $\mathrm{Cl})$. The average frequency of ORF $7 \mathrm{~b}$ mutation is estimated to be $0.4 \%(0.1,1.4)$. We observed heterogeneity $\left(I^{2}: 72 \%, Q=25, P\right.$ $<0.001$ ) among these studies (Fig 3, G).

\section{8 - Analysis of ORF8a mutation}

In all non-synonymous mutation groups, the average rate of ORF 8 a mutation is $1.8 \%(1.5,2.1)$. Based on analysis by $95 \%$ confidence interval on fixed-effect model, there is no heterogeneity across these studies $\left({ }^{2}: 29.82 \%, Q=9.97, P<0.190\right)(F i g ~ 3, H)$.

\section{9 - Analysis of ORF10amutation}

According to the heterogeneity between the results of the studies, the overall prevalence of ORF 10a mutation $0.5 \%(0.2,1)$ with the confidence interval of $95 \%$ based on random effect model is $\left(I^{2}: 50.84 \%, Q=14.24, P<0.047\right)$ (Fig $\left.3, I\right)$.

\section{0 - Analysis of ORF6 mutation}

Based on the heterogeneity for ORF 6 mutation $\left(1^{2}: 74.18 \%, \mathrm{Q}=27.11, \mathrm{P}<0.001\right)$ using the random effects model, the prevalence of mutation is estimated as $0.7 \%(95 \% \mathrm{Cl}: 0.2,1.7)(\mathrm{Fig} 3, \mathrm{~J})$.

\section{1 - Analysis of E mutation}

The heterogeneity indices show the heterogeneity between the primary results of $E$ mutation. Therefore, the random effect model is applied for combining the results $\left(I^{2}:=56.68 \% \mathrm{Q}=16.16, \mathrm{P}<0.024\right)$. The pooled event rates for mutations of ORF6 is estimated as $0.4 \%(0.2,1.1)($ Fig $3, \mathrm{~K})$.

\section{Analysis of mutationsamong total mutation}

In the current Meta-analysis, review 5 primary studies. S, N, M, ORF 3a, ORF 7a, ORF 7b and NSP mutations were examined among total mutations.

\section{1 - Analysis of $\mathrm{S}$ mutation}

Based on the significant heterogeneity observed among the results $\left(Q=45.6, P=0.000\right.$ and $\left.\mathrm{I}^{2}=91.12 \%\right)$, the pooled event rate $(95 \%$ $\mathrm{Cl}$ ) of developing $S$ mutation using random model was estimated as $18.4 \%(13.7,24.4)$ (Fig 3, L).

\section{2 - Analysis of ORF3a mutation}

The forest plot indicated that the overall frequency of ORF3a mutation is $3.9 \%(2.5,6)$ and with the compounding of the results, the overall prevalence of ORF3a mutation with the confidence interval of $95 \%$ and based on random effect model is $\left({ }^{2}: 60.33 \%\right.$, 
$\mathrm{Q}=10.08, \mathrm{P}<0.039)$. Also, the results of the heterogeneity studies show that there is a heterogeneity among the primary results of the studies (Fig 3, M).

\section{3 - Analysis of M mutation}

The prevalence of total mutation according to the NSP group by $95 \%$ confidence interval in different studies is shown in the forest plot $31.6 \%(21,44.6)$. The results of the analysis manifest heterogeneity among reported studies $\left(P=0.00 ; I^{2}=90.47 \%, Q=42\right)(F i g 3$, N).

\section{4 - Analysis of $\mathrm{N}$ mutation}

According to the severe heterogeneity, the random effect meta-analysis is performed $\left(P=0.00 ; I^{2}=96.35 \%, Q=109.83\right)$. The overall mutation of $\mathrm{N}$ using the random effect model meta-analysis is $10.5 \%(95 \% \mathrm{Cl} ; 5.1,20.4)($ Fig 3,0$)$.

\section{5 - Analysis of M mutation}

Heterogeneity indices for primary results for $\mathrm{M}$ were not statistically significant $\left(\mathrm{I}^{2}: 16.55 \%, \mathrm{Q}=4.79, \mathrm{P}<0.309\right)$. Therefore, using fixed-effect model, the event rate for $\mathrm{M}$ mutation was estimated as $2.1 \%(95 \% \mathrm{Cl}: 1.7,2.5)($ Fig $3, \mathrm{P})$.

\section{6 - Analysis of ORF7a mutation}

More ever there was no significant heterogeneity between the results of primary studies regarding the effect of ORF $7 \mathrm{a}$ ( ${ }^{2}$ : $46.89 \%$, $\mathrm{Q}=7.53, \mathrm{P}<0.11)$. The pooled event rate for ORF7a was estimated at $1.8 \%(95 \% \mathrm{Cl}: 1.5,2.2)($ Fig $3, \mathrm{Q})$.

\section{7 - Analysis of ORF7b mutation}

In this study, it is observed a great heterogeneity between the results of studies regarding the effect of ORF $7 \mathrm{~b}\left(\mathrm{I}^{2}: 58.07 \%, \mathrm{Q}=9.54, \mathrm{P}\right.$ $<0.049)$. Therefore, the random effects model was applied that estimated the pooled event rate for this mutation as $0.4 \%$ ( $95 \% \mathrm{Cl}$ : $0.1,1.2)$. (Fig 2, R).

\section{Discussion}

Research on the variation in the SARS-CoV-2 genome sequence is necessary for the examination of disease course of COVID-19, disease progression, monitoring, controlling and treatment of SARS- CoV-2 infection [28]. In this present study, the genome sequences of MERS-CoV-2 isolates were examined. The impact of epitope deletion among non-synonymous mutations was the aim of this study which is related to immune escape and pathogenesis. Our study showed that according to the pooled prevalence (95\% confidence interval) of mutations, the S variation was shown high frequency $16.4 \%(13.6,16.6)$ among non-synonymous and NSP was the most common mutant among total mutation $31.6 \%(21,44.6)$.

The high mutation of RNA viruses causes genetic variation, virus evolution and it is a strategy to escape the immune system and drug resistance. The SARS-CoV-2 complete genomes with different geographical locations are essential for detecting the genetic variations in the virus that causes viral shedding [29]. Several genome variations in the SARS- CoV-2, such as nucleocapsid (N) protein, ORF4a and the surface protein S associated with the host immune system [30]. Research indicates that genetic variations of SARS-COV-2 can transmit during the early stage of the epidemic; however, genomes are remarkably stable, and they are not able to evolve rapidly [31].

It is demonstrated that the fatality rate of COVID-19 can vary in different populations, and the level of virulence varies among humans [32]. A larger number of specific mutations with a rapid transmission is detected in Italy, Spain and US and it is related to critical conditions [33]. However, it is demonstrated that genome sequences of SARS-CoV-2 are similar with only a few mutations, but some countries such as North America and Europe are shown the heavily affected regions and Australia, Asia and Africa less affected with sequence variation [34,35]. Research shows that the variation of RNA viruses is pivotal during an outbreak and it depends on nucleotide substitutions. Based on the viral transmission, the viral mutation rates vary in different viruses and help the virus in host adaptation [36]. 
Finding non-synonymous mutations through the database is useful for identifying mutations and their modes of transmission [37]. There are some new variants such as (deletion 69-70, deletion 144, N501Y, A570D, D614G, P681H, T716I, S982A, D1118H) are defined in the spike protein of SARS-CoV-2. The novel mutation, (N501Y) which is found in the UK virus variant is located in the receptor-binding domain (RBD). The severity and infectious diseases of the UK variant remain unknown [13]. In SARS-CoV-2 viruses, D614G, is a common mutation spike protein around the world. Also, it is proposed that the highest frequency of spike D614G mutation (S) may be associated with higher viral loads, cellular infectivity, infection severity and lethal outcome in COVID-19 [38]. The relation between high viral loads in the upper respiratory tracts and G clade is measured by RT PCR. It is suggested that the sensitivity of the $G$ variant of SARS-CoV-2 spike to neutralizing antibody is more sensitive than D variant [8]. It is reported that D to G mutation at position 614 (D614G) in the spike glycoprotein which is originated from Europe or China is a significant variation in changes of the secondary structure of protein [39] [8]. D614G mutation started in all affected regions such as Bangladesh (with 95.6\% D614G mutation), Italy, Spain, North America and European countries [40] [41]. , amino-acid substitution $1109(\mathrm{~F} \rightarrow \mathrm{L})$ and 76th (S_T76I) position at spike protein found in Bangladeshi and Indonesian strain respectively [37]. It is also suggested that mutation in RNA-dependent RNA-polymerase (RdRp) and D614G increase SARS-CoV-2 transmission and promote the infectivity of SARS-CoV-2 [42]. The study of 12,300 SARS-CoV-2 genome sequences from different countries reported that D614G and P4715L variation was associated with higher COVID-19 mortality [43].

It is evident that ORF1ab P4715L (nsp 12) plays a pivotal role in viral replication and it is reported that ORF1ab-V378I mutation is associated with COVID-19 infection in Taiwan, Australia and Germany [4] [44]. Also, three mutations, including (M5865V, S5932F) and (R203K) described in ORF1ab and N respectively [45]. It is noticed that mutation in Nucleocapsid (N protein) (R203K and G204R) observed in Italy, Spain, India and France and also N_S202N mutant was detected in Saudi Arabia [46] [47].

Our study shows that substitution in S protein (D614G) is the dominant variant in Asia, Oceania, Europe, North America mutant, Italy, Morocco and Saudi Arabia and led to severe respiratory infections and death in these regions. Genomic mutation analysis of SARS-CoV-2 strains may provide knowledge about different biological infrequent mutations and their relationships of viral transmission, pathogenicity, infectivity, and fatality rates between SARS-CoV-2 and human cells.

\section{Declarations}

\section{Acknowledgments}

This present study was funded by, Mazandaran University of Medical Sciences, Grant/Award Number: IR.MAZUMS.REC.1399.8702

\section{Conflict of interest}

The authors declare there is no conflict of interest.

\section{Authors contributions}

Tahoora Mousavi and Reza Valadan conceived and designed the study and wrote the manuscript. Mehrdad Gholami, and Monireh Golpour performed the literature search and collected the data. Mehryar Zargari and Mohammadreza Haghshenas performed the literature review. Reza Alizadeh-Navaei performed the statistical analysis, and all authors read and approved the final version of the manuscript.

\section{ORCID}

Tahoora Mousavi 0000-0003-2505-370X

\section{References}

1. Pimentel, R.M.M. et al. (2020) The dissemination of COVID-19: an expectant and preventive role in global health. Journal of Human Growth and Development 30 (1), 135-140.

2. Organization, W.H. (2020) COVID-19 weekly epidemiological update, 1 December 2020. 
3. Adedokun, K.A. et al. (2020) A close look at the biology of SARS-CoV-2, and the potential influence of weather conditions and seasons on COVID-19 case spread. Infectious Diseases of Poverty 9 (1), 1-5.

4. Toyoshima, Y. et al. (2020) SARS-CoV-2 genomic variations associated with mortality rate of COVID-19. Journal of human genetics 65 (12), 1075-1082.

5. Pachetti, M. et al. (2020) Emerging SARS-CoV-2 mutation hot spots include a novel RNA-dependent-RNA polymerase variant. Journal of Translational Medicine 18, 1-9.

6. Kumar, B.K. et al. (2020) Mutational analysis unveils the temporal and spatial distribution of G614 genotype of SARS-CoV-2 in different Indian states and its association with case fatality rate of COVID-19. bioRxiv.

7. Wang, C. et al. (2020) The establishment of reference sequence for SARS-CoV-2 and variation analysis. Journal of medical virology 92 (6), 667-674.

8. Korber, B. et al. (2020) Tracking changes in SARS-CoV-2 Spike: evidence that D614G increases infectivity of the COVID-19 virus. Cell 182 (4), 812-827. e19.

9. Biswas, N.K. and Majumder, P.P. (2020) Analysis of RNA sequences of 3636 SARS-CoV-2 collected from 55 countries reveals selective sweep of one virus type. Indian J. Med. Res.

10. Fernández, A. (2020) Structural impact of mutation D614G in SARS-CoV-2 spike protein: enhanced infectivity and therapeutic opportunity. ACS medicinal chemistry letters 11 (9), 1667-1670.

11. Plante, J.A. et al. (2020) Spike mutation D614G alters SARS-CoV-2 fitness. Nature, 1-6.

12. Bal, A. et al. (2021) Two-step strategy for the identification of SARS-CoV-2 variant of concern 202012/01 and other variants with spike deletion H69-V70, France, August to December 2020. Eurosurveillance 26 (3), 2100008.

13. Leung, K. et al. (2021) Early transmissibility assessment of the N501Y mutant strains of SARS-CoV-2 in the United Kingdom, October to November 2020. Eurosurveillance 26 (1), 2002106.

14. Cheng, M.H. et al. (2021) Impact of South African 501. V2 Variant on SARS-CoV-2 Spike Infectivity and Neutralization: A Structure-based Computational Assessment. bioRxiv.

15. Franceschi, V.B. et al. (2021) Genomic Epidemiology of SARS-CoV-2 in Esteio, Rio Grande do Sul, Brazil. medRxiv.

16. Voloch, C.M. et al. (2020) Genomic characterization of a novel SARS-CoV-2 lineage from Rio de Janeiro, Brazil. medRxiv.

17. Thomson, E.C. et al. (2020) The circulating SARS-CoV-2 spike variant N439K maintains fitness while evading antibodymediated immunity. bioRxiv.

18. Hodcroft, E.B. et al. (2020) Emergence and spread of a SARS-CoV-2 variant through Europe in the summer of 2020. MedRxiv.

19. Assessment, R.R. (2020) Detection of new SARS-CoV-2 variants related to mink. Eur. Cent. Dis. Prev. Control.

20. Daniloski, Z. et al. (2020) The Spike D614G mutation increases SARS-CoV-2 infection of multiple human cell types. bioRxiv.

21. Dutta, N.K. et al. (2020) The nucleocapsid protein of SARS-CoV-2: a target for vaccine development. Journal of virology 94 (13).

22. Maitra, A. et al. (2020) Mutations in SARS-CoV-2 viral RNA identified in Eastern India: Possible implications for the ongoing outbreak in India and impact on viral structure and host susceptibility. Journal of Biosciences 45 (1).

23. Jamwal, S. et al. (2020) An updated insight into the molecular pathogenesis, secondary complications and potential therapeutics of COVID-19 pandemic. Life Sciences 257, 118105.

24. Rehman, S. et al. (2020) Identification of novel mutations in SARS-COV-2 isolates from Turkey. Archives of Virology 165 (12), 2937-2944.

25. Hassan, S.S. et al. (2020) Pathogenetic perspective of missense mutations of orf3a protein of sars-cov2. bioRxiv.

26. Tozzi, A. SUSD1: A CANDIDATE GENE FOR COVID-19 SEVERITY.

27. Issa, E. et al. (2020) SARS-CoV-2 and ORF3a: Non-Synonymous Mutations and Polyproline Regions. BioRxiv.

28. Wang, F. et al. (2020) Initial Whole Genome Sequencing and Analysis of the Host Genetic Contribution to COVID-19 Severity and Susceptibility. medRxiv.

29. Gong, Y.N. et al. (2020) SARS-CoV-2 genomic surveillance in Taiwan revealed novel ORF8-deletion mutant and clade possibly associated with infections in Middle East. Emerging Microbes and Infections 9 (1), 1457-1466. 
30. AlBalwi, M.A. et al. (2020) Evolving sequence mutations in the Middle East Respiratory Syndrome Coronavirus (MERS-CoV). J Infect Public Health 13 (10), 1544-1550.

31. Zhao, J. et al. (2020) Snapshot of the evolution and mutation patterns of SARS-CoV-2. bioRxiv.

32. Malki, Z. et al. (2020) Association between weather data and COVID-19 pandemic predicting mortality rate: Machine learning approaches. Chaos, Solitons \& Fractals 138, 110137.

33. Laamarti, M. et al. (2020) Large scale genomic analysis of 3067 SARS-CoV-2 genomes reveals a clonal geo-distribution and a rich genetic variations of hotspots mutations. PLoS One 15 (11), e0240345.

34. Yamamoto, N. and Bauer, G. (2020) Apparent difference in fatalities between Central Europe and East Asia due to SARS-COV-2 and COVID-19: Four hypotheses for possible explanation. Medical hypotheses 144, 110160.

35. Lu, R. et al. (2020) Genomic characterisation and epidemiology of 2019 novel coronavirus: implications for virus origins and receptor binding. The Lancet 395 (10224), 565-574.

36. Hanada, K. et al. (2004) A large variation in the rates of synonymous substitution for RNA viruses and its relationship to a diversity of viral infection and transmission modes. Molecular biology and evolution 21 (6), 1074-1080.

37. Islam, O.K. et al. (2020) Emergence of European and North American mutant variants of SARS-CoV-2 in South-East Asia. Transbound Emerg Dis.

38. Kim, J.S. et al. (2020) Genome-Wide Identification and Characterization of Point Mutations in the SARS-CoV-2 Genome. Osong Public Health Res Perspect 11 (3), 101-111.

39. Gupta, A.M. et al. (2020) Non-synonymous mutations of SARS-CoV-2 leads epitope loss and segregates its variants. Microbes Infect.

40. Hodcroft, E.B. et al. (2020) Emergence and spread of a SARS-CoV-2 variant through Europe in the summer of 2020. medRxiv.

41. Hasan, M.M. et al. (2020) Global and Local Mutations in Bangladeshi SARS-CoV-2 Genomes. bioRxiv.

42. Biswas, S.K. and Mudi, S.R. (2020) RNA-dependent RNA polymerase and spike protein mutant variants of SARS-CoV-2 predominate in severely affected COVID-19 patients.

43. Pandey, U. et al., High Prevalence of SARS-CoV-2 Genetic Variation and D614G Mutation in Pediatric Patients with COVID-19, Open Forum Infectious Diseases, 2020.

44. Gong, Y.-N. et al. (2020) SARS-CoV-2 genomic surveillance in Taiwan revealed novel ORF8-deletion mutant and clade possibly associated with infections in Middle East. Emerging microbes \& infections 9 (1), 1457-1466.

45. Ippodrino, R. et al. (2020) Emerging SARS-CoV-2 mutation hot spots include a novel RNA-dependent-RNA polymerase variant.

46. Koyama, T. et al. (2020) Variant analysis of SARS-CoV-2 genomes. Bulletin of the World Health Organization 98 (7), 495.

47. Islam, O. et al. (2020) Emergence of European and North American mutant variants of SARS-CoV-2 in Southeast Asia.

48. Korber, B. et al. (2020) Spike mutation pipeline reveals the emergence of a more transmissible form of SARS-CoV-2. bioRxiv.

49. Su, Y.C. et al. (2020) Discovery and genomic characterization of a 382-nucleotide deletion in ORF7b and ORF8 during the early evolution of SARS-CoV-2. MBio 11 (4).

50. Lai, A. et al. (2020) Molecular tracing of SARS-CoV-2 in Italy in the first three months of the epidemic. Viruses 12 (8), 798.

51. Zhao, J. et al. (2020) Snapshot of the evolution and mutation patterns of SARS-CoV-2. bioRxiv.

52. Poterico, J.A. and Mestanza, O. (2020) Genetic variants and source of introduction of SARS-CoV-2 in South America. Journal of Medical Virology.

53. Nguyen, T.T. et al. (2020) Genetic diversity of SARS-CoV-2 and clinical, epidemiological characteristics of COVID-19 patients in Hanoi, Vietnam. PloS one 15 (11), e0242537.

54. Laamarti, M. et al. (2020) Genome sequences of six SARS-CoV-2 strains isolated in morocco, obtained using oxford nanopore minion technology. Microbiology Resource Announcements 9 (32).

55. AlBalwi, M.A. et al. (2020) Evolving sequence mutations in the Middle East Respiratory Syndrome Coronavirus (MERS-CoV). Journal of infection and public health 13 (10), 1544-1550.

56. Gupta, A.M. et al. (2020) Non-synonymous mutations of SARS-CoV-2 leads epitope loss and segregates its variants. Microbes and infection 22 (10), 598-607. 
57. Kim, J.-S. et al. (2020) Genome-Wide Identification and Characterization of Point Mutations in the SARS-CoV-2 Genome. Osong Public Health and Research Perspectives 11 (3), 101.

58. Laha, S. et al. (2020) Characterizations of SARS-CoV-2 mutational profile, spike protein stability and viral transmission. Infection, Genetics and Evolution 85, 104445.

59. Laamarti, M. et al. (2020) Large scale genomic analysis of 3067 SARS-CoV-2 genomes reveals a clonal geodistribution and a rich genetic variations of hotspots mutations. bioRxiv.

60. Lai, A. et al. (2020) Molecular tracing of SARS-CoV-2 in Italy in the first three months of the epidemic. Viruses 12 (8).

61. Jin, X. et al. (2020) Virus strain from a mild COVID-19 patient in Hangzhou represents a new trend in SARS-CoV-2 evolution potentially related to Furin cleavage site. Emerging Microbes and Infections 9 (1), 1474-1488.

62. Wang, R. et al. (2020) Mutations on COVID-19 diagnostic targets. arXiv preprint arXiv:2005.02188.

\section{Table 2}

Table 2: Geographic distribution of mutant variants of SARS-CoV-2 


\begin{tabular}{|c|c|c|c|}
\hline ame & Location & Mutation Position & Reference \\
\hline apore & $\begin{array}{l}\text { ORF1ab } \\
\text { ORF3a } \\
\text { N } \\
\text { ORF8 }\end{array}$ & $\begin{array}{l}\text { C8517T, ,T17459C (V5820A) } \\
\text { T2449C (F817L) } \\
\text { C176A ( A59D) } \\
\text { C595T (P199S) }\end{array}$ & {$[44]$} \\
\hline $\begin{array}{l}\text { JGU- } \\
\text { ran) }\end{array}$ & $\begin{array}{l}\text { ORF1ab } \\
\text { S } \\
\text { ORF8 }\end{array}$ & $\begin{array}{l}\text { C8517T, A16577G (K5526R) } \\
\text { C145T (H49Y), C2651T (S884F) }\end{array}$ & [44] \\
\hline 3/Los & $\begin{array}{l}\text { ORF1ab } \\
\text { S }\end{array}$ & $\begin{array}{l}\text { F924F, P4715L } \\
\text { D614G }\end{array}$ & [43] \\
\hline $\begin{array}{l}\text { 3/ Asia, } \\
\text {,, North }\end{array}$ & $\begin{array}{l}\text { ORF1ab } \\
\text { ORF9a } \\
\text { ORF3a } \\
\text { ORF8a }\end{array}$ & $\begin{array}{l}\text { (1397 nsp2, } 2891 \text { nsp3, } 14408 \text { RdRp, } 17746 \text { and } 17857 \text { nsp143, } 18060 \text { nsp14), } \\
\text { (23403, spike protein) } \\
\text { (28881, nucleocapsid phosphoprotein) } \\
\text { (nt 26143) } \\
\text { (nt 28144) }\end{array}$ & {$[45]$} \\
\hline & $\begin{array}{l}\text { ORF1ab } \\
\mathrm{S} \\
\mathrm{N}\end{array}$ & $\begin{array}{l}\text { P4715L, L3606F } \\
\text { D614G } \\
\text { R203K/G204R, P13L, 203K/204R }\end{array}$ & {$[4]$} \\
\hline IID & $\mathrm{S}$ & $\begin{array}{l}\text { D614G, L5F, } \\
\text { L8V/W, H49Y, Y145H/del, Q239K, V367F, G476S, V483A, V615I/F, A831V, D839Y/N/E, P1263L, }\end{array}$ & {$[48]$} \\
\hline apore & $\begin{array}{l}\text { ORF7b } \\
\text { ORF8 }\end{array}$ & 382-nt deletion & [49] \\
\hline ralia & $\begin{array}{l}\text { ORF7b } \\
\text { ORF8 }\end{array}$ & 138-nt deletion & {$[49]$} \\
\hline gladesh & ORF8 & 345-nt deletion & {$[49]$} \\
\hline 9/Spain & ORF8 & 62-nt deletion & {$[49]$} \\
\hline 3/Italy & $\begin{array}{l}\text { ORF 1ab } \\
\text { M } \\
\text { ORF 7a } \\
\text { ORF 3a } \\
\text { N }\end{array}$ & $\begin{array}{l}\text { (S443F, H3076Y, L3606F, P4715L, E5689D, R5919K) } \\
\text { (D3G) } \\
\text { (G70C) } \\
\text { (A570D, D614G, G1046V) } \\
\text { (G251V) } \\
\text { (R203K-G204R, V246I) }\end{array}$ & [50] \\
\hline $\begin{array}{l}\text { GISAID } \\
\text { atabase }\end{array}$ & $\begin{array}{l}\text { ORF 1ab, ORF } \\
\text { 1a,ORF8 } \\
\text { S, ORF 3a, N }\end{array}$ & $\begin{array}{l}\text { (nsp12, nsp13, RdRp) } \\
\text { (nsp2, nsp6) }\end{array}$ & {$[51]$} \\
\hline gladesh & $\begin{array}{l}\mathrm{S} \\
\mathrm{N}\end{array}$ & $\begin{array}{l}\text { I300F (nsp2), P4715L (nsp12), D614G } \\
\text { R203K, G204R (N protein) }\end{array}$ & {$[41]$} \\
\hline i states & $\begin{array}{l}\text { 2'-O-ribose } \\
\text { methyltransferase } \\
\text { RNA-dependent } \\
\text { RNA polymerase } \\
\text { Predicted } \\
\text { phosphoesterase, } \\
\text { papain-like } \\
\text { proteinase }\end{array}$ & $\begin{array}{l}\text { N298L } \\
\text { V871I, A88V, P314L } \\
\text { P1103L, S1285F, S1197R, A994D, T1198K }\end{array}$ & {$[6]$} \\
\hline
\end{tabular}




\begin{tabular}{|c|c|c|c|}
\hline & $\begin{array}{l}\text { Transmembrane } \\
\text { protein } \\
\text { NSP } \\
\text { 3'-to-5' } \\
\text { exonuclease } \\
\text { ORF3a } \\
\text { ORF8 } \\
\text { S } \\
\text { NP }\end{array}$ & $\begin{array}{l}\text { D279N, L37F. A380V, } \\
\text { G339S, Q496P, S202N } \\
\text { T372I, L177F } \\
\text { L46F, Q57H } \\
\text { L84S } \\
\text { L54F, D614G } \\
\text { P13L, S194L, RG203KR }\end{array}$ & \\
\hline $\begin{array}{r}\text { South } \\
\text { nerican }\end{array}$ & $\begin{array}{l}\text { ORF 1b } \\
\text { ORF 1a } \\
\text { ORF 3a } \\
\text { M } \\
\text { ORF } 8 \\
\text { N }\end{array}$ & $\begin{array}{l}\text { D614G, E1207V } \\
\text { G392D, T708I, I739V, P765S, A876T, A1043V, N2894D, F3071Y, G3334S, L3606F } \\
\text { Q57H, G196V, G251V } \\
\text { T175M } \\
\text { L84S } \\
\text { D103Y, R191C, S197L, R203K, G204R, G238C }\end{array}$ & [52] \\
\hline e & $\begin{array}{l}\text { 3' UTR } \\
\text { 5' UTR } \\
\text { N } \\
\text { ORF } 8 \\
\text { M } \\
\text { ORF } 3 \\
\text { S } \\
\text { ORF1ab }\end{array}$ & $\begin{array}{l}\text { G204R } \\
- \\
\text { S194L, R203K, S202N } \\
\text { L84S } \\
- \\
\text { Q57H } \\
\text { D614G, A879S } \\
\text { A1812D (nsp3), L3606F (nsp6), P4715L (RdRp) }\end{array}$ & [42] \\
\hline $\begin{array}{l}\text { orthern } \\
\text { Tietnam }\end{array}$ & $\begin{array}{l}\text { S } \\
\text { ORF 3a } \\
\text { M } \\
\text { ORF 7a } \\
\text { ORF 7b }\end{array}$ & $\begin{array}{l}\text { L54F, S254F, C1250F, D614G } \\
\text { Q57H, G251V } \\
\text { D3G, V70F } \\
\text { S81L, L96F, L102_I103del } \\
\text { R203K; G204R, S180I, } \\
\text { A211V, Q283H } \\
\text { Gly82_Val86del, Met85del (nsp1), T85I, G212D, 559V, P585S (nsp2) } \\
\text { A58T, T428I, R646W, L672F, G730D, P1103L, K1186R, M1901I (nsp3), } \\
\text { D477N (nsp4), } \\
\text { G15S (nsp5), } \\
\text { L37F (nsp6), } \\
\text { D161V, P323L, V338F (nsp12) } \\
\text { R595S(nsp13) } \\
\text { V320L(nsp15) } \\
\text { P134S, T140I (nsp16) }\end{array}$ & [53] \\
\hline $\begin{array}{r}\text { Ith-East } \\
\text { Asia }\end{array}$ & $\begin{array}{l}\text { S } \\
\text { N } \\
\text { NSP }\end{array}$ & $\begin{array}{l}\text { D614G } \\
\text { R203K, G204R, P13L, Q57H, NS8_L84S, L37F, P323L } \\
\text { A97V, T1198K }\end{array}$ & [47] \\
\hline Iorocco & $\mathrm{S}$ & D614G & [54] \\
\hline Arabia & $\mathrm{S}$ & P97 L, T424I, C1313S, W553R, S950T, R700L, S191 P, S459T, V26 L, Q1009L & [55] \\
\hline
\end{tabular}

Page 13/18 


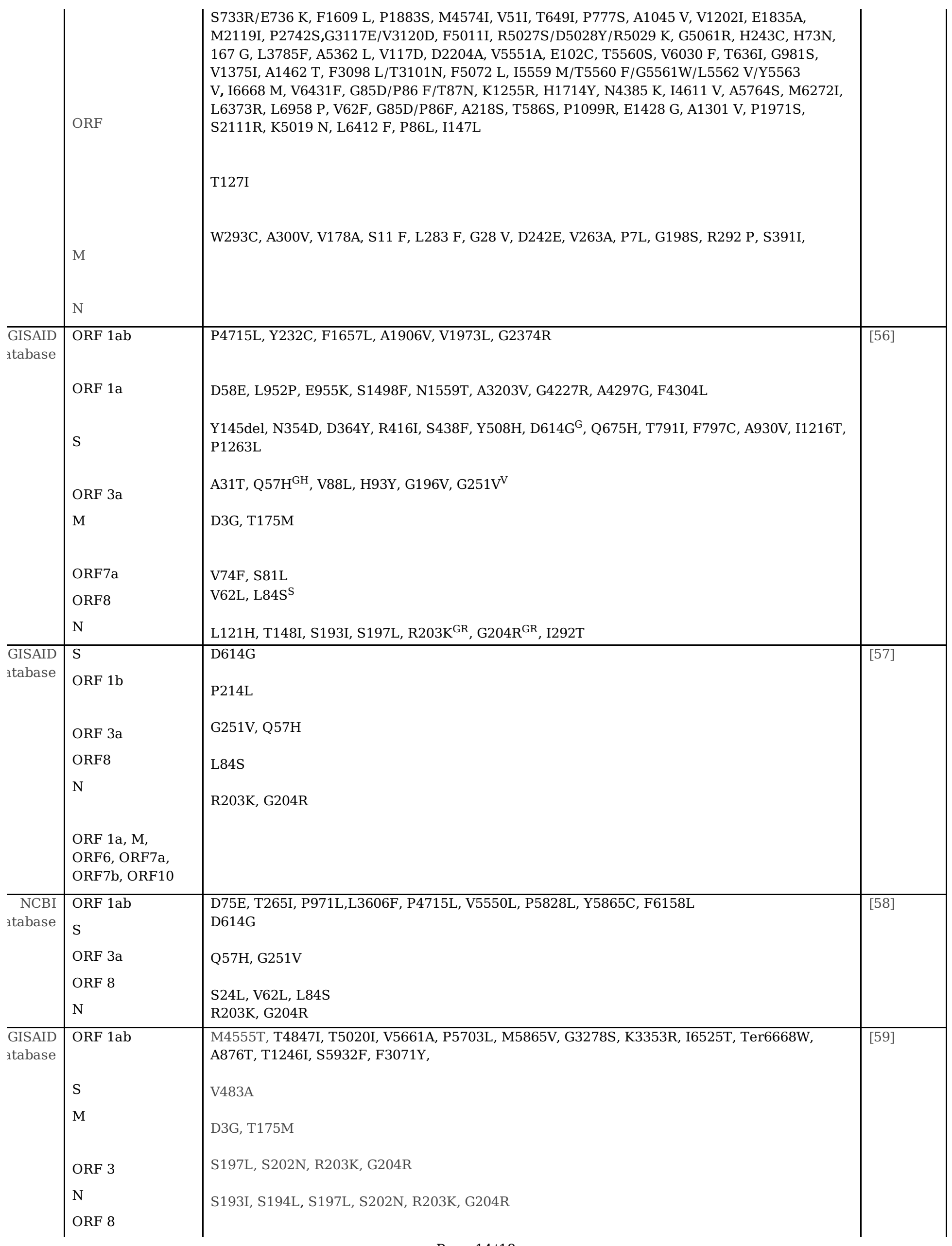


V62L, L84S

Table 2(A): Frequency of mutations among non-synonymous mutation included in Meta-analysis

\begin{tabular}{|c|c|c|c|c|c|c|c|c|c|c|c|c|c|c|c|}
\hline e & $\begin{array}{l}\text { First } \\
\text { author }\end{array}$ & Language & $\begin{array}{l}\text { Area of } \\
\text { study }\end{array}$ & $\begin{array}{l}\text { non-synonymous } \\
\text { sample size }\end{array}$ & $\mathrm{S} \%$ & $\mathrm{~N} \%$ & M\% & $\begin{array}{l}\text { ORF } \\
1 \mathrm{a} / 1 \mathrm{~b} \\
\%\end{array}$ & $\begin{array}{l}\text { ORF } \\
3 a \%\end{array}$ & $\begin{array}{l}\text { ORF } \\
7 a \%\end{array}$ & $\begin{array}{l}\text { ORF } \\
7 \mathrm{~b} \% \\
\end{array}$ & $\begin{array}{l}\text { ORF } \\
8 \mathrm{a} \%\end{array}$ & $\begin{array}{l}\text { ORF } \\
10 a \%\end{array}$ & ORF6\% & $\mathrm{E} \%$ \\
\hline & $\begin{array}{l}\text { Alessia } \\
(2020)\end{array}$ & English & Italy & 159 & 11.94 & 3.77 & 2.51 & 70.44 & 7.54 & 1.88 & 0.62 & 0.62 & 0.62 & NA & NA \\
\hline & $\begin{array}{l}\text { Kim } \\
(2020)\end{array}$ & English & GISAID & 1352 & 13.46 & 8.8 & 1.55 & NA & 5.76 & 2.58 & 0.59 & 2.36 & 0.81 & 1.40 & 0.88 \\
\hline & $\begin{array}{l}\text { Hasan } \\
(2020)\end{array}$ & English & Bangladesh & 1602 & 15.60 & 36.14 & 0.811 & 39.51 & 3.30 & 2.18 & 0.06 & 1.87 & 0.18 & 0.18 & 0.12 \\
\hline & $\begin{array}{l}\text { Islam } \\
(2020)\end{array}$ & English & $\begin{array}{l}\text { South-East } \\
\text { Asia }\end{array}$ & 78 & 16.66 & 11.53 & 3.84 & NA & NA & NA & NA & NA & NA & NA & 1.2 \\
\hline
\end{tabular}

Table 2(B): Frequency of mutations among total mutation included in Meta-analysis

\begin{tabular}{|c|c|c|c|c|c|c|c|c|c|c|c|}
\hline ence & First author & Language & Area of study & Total mutation sample size & $\mathrm{S} \%$ & $\mathrm{~N} \%$ & $\mathrm{M} \%$ & $\begin{array}{l}\text { ORF } \\
3 a \%\end{array}$ & ORF 7a\% & ORF $7 \mathrm{~b} \%$ & $\begin{array}{l}\text { NSP } \\
\%\end{array}$ \\
\hline & Biswas (2020) & English & GISAID & 504 & 16.26 & 7.14 & 1.78 & 3.96 & $\mathrm{~N} / \mathrm{A}$ & $\mathrm{N} / \mathrm{A}$ & $\mathrm{N} / \mathrm{A}$ \\
\hline & Wang (2020) & English & GISAID & 4796 & 1.2 & 0.07 & 2.18 & 4.81 & 1.83 & 0.2 & 44.14 \\
\hline & Nguyen (2020) & English & GISAID & 167 & 26.34 & 23.95 & 1.19 & $\mathrm{~N} / \mathrm{A}$ & 2.39 & 1.19 & 40.11 \\
\hline & Utsav (2020) & English & GISAID & 273 & 15.38 & $\mathrm{~N} / \mathrm{A}$ & $\mathrm{N} / \mathrm{A}$ & $\mathrm{N} / \mathrm{A}$ & $\mathrm{N} / \mathrm{A}$ & $\mathrm{N} / \mathrm{A}$ & $\mathrm{N} / \mathrm{A}$ \\
\hline & Nguyen (2020) & English & GISAID & 171 & 25.73 & 23.39 & 1.16 & 4.67 & 2.33 & 1.16 & 41.52 \\
\hline
\end{tabular}

\section{Figures}




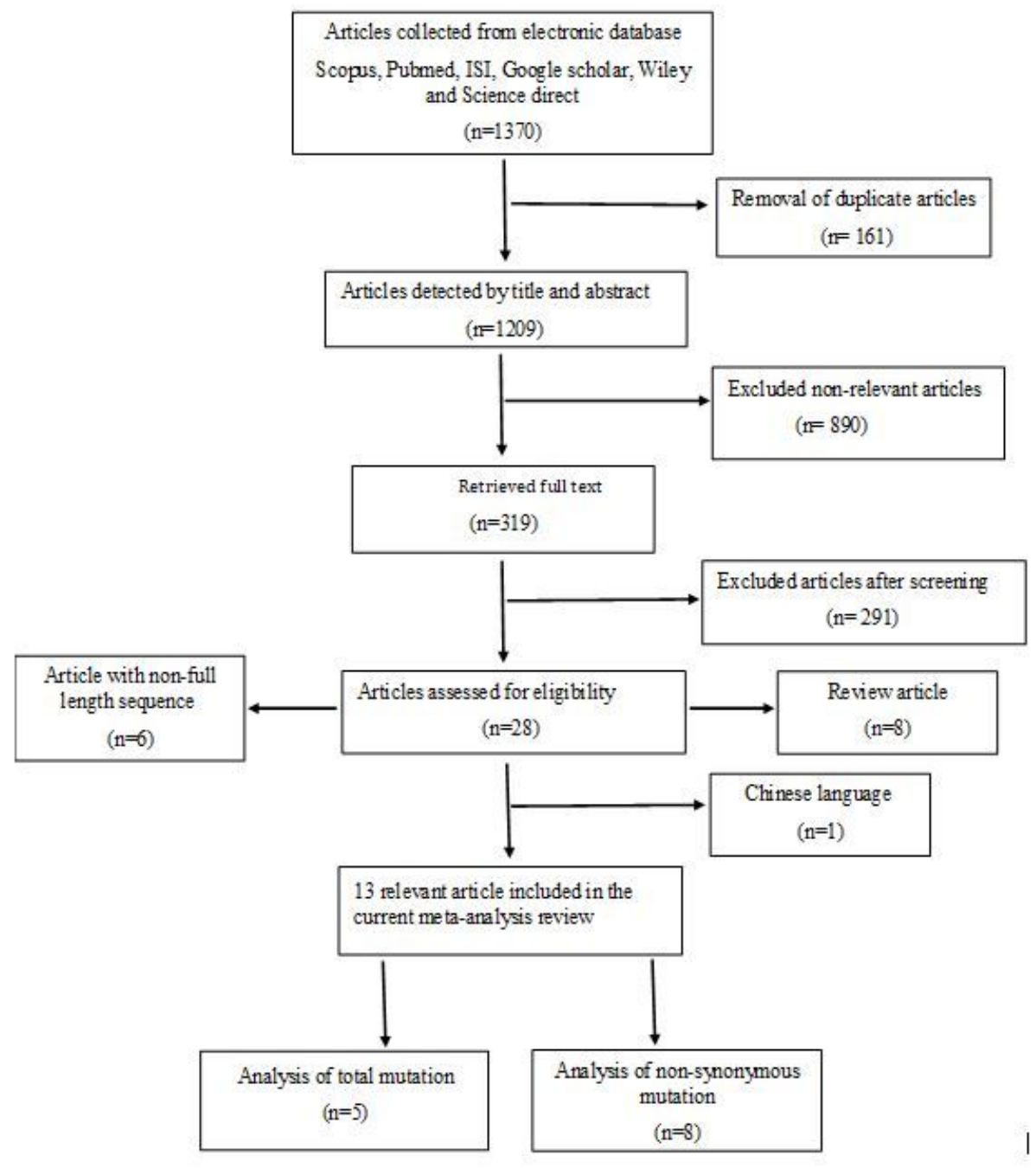

\section{Figure 1}

Flow chart of the literature search strategy for selection and including primary articles

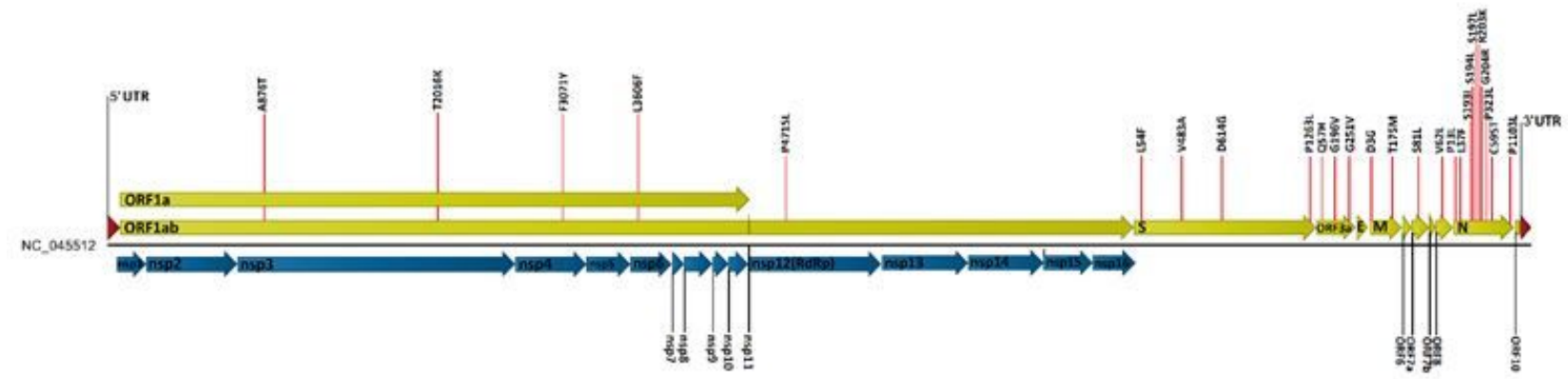

\section{Figure 2}

Frequently mutated residues among COVID-19 sequences from different locations 


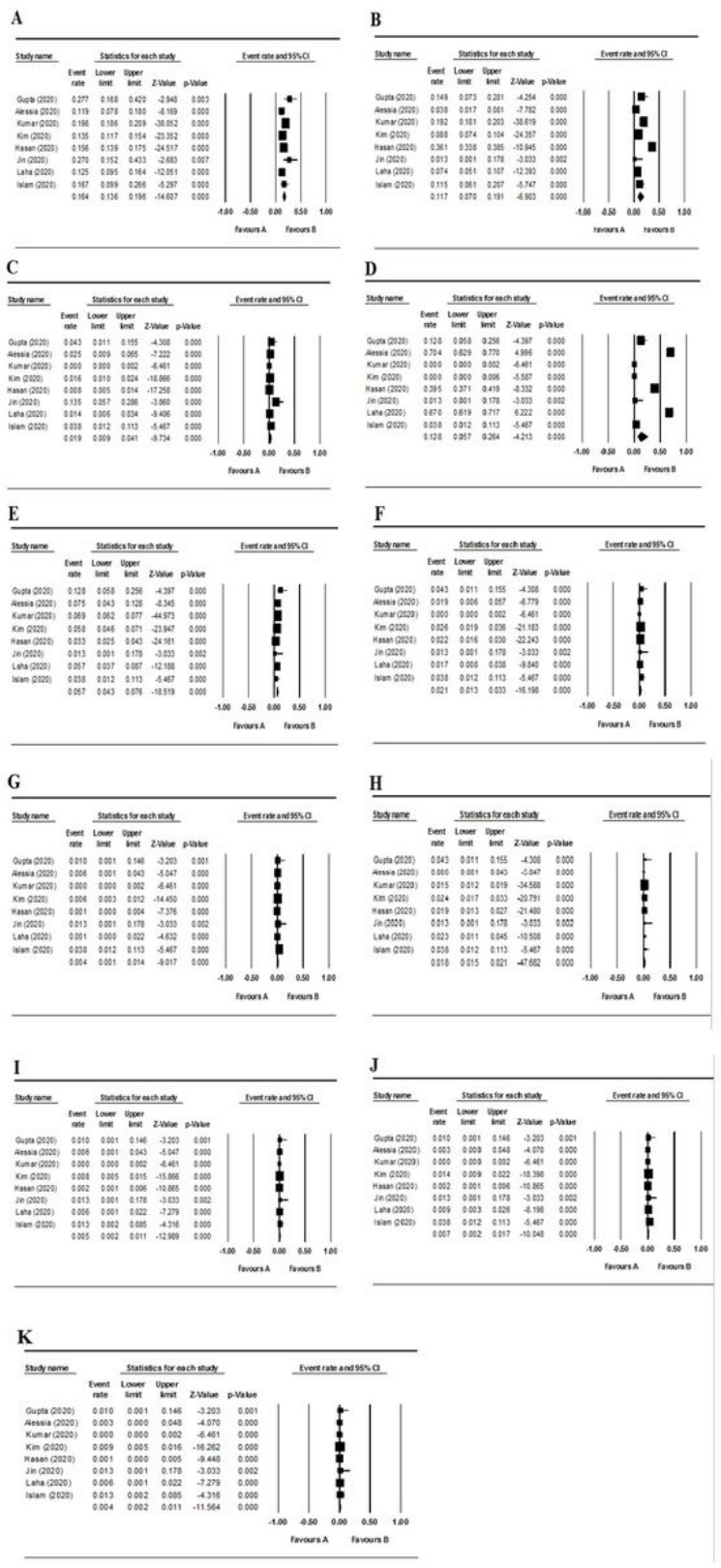

\section{Figure 3}

A: Estimation of mutations in S protein among non-synonymous mutations. B: Estimation of mutations in $\mathrm{N}$ protein among nonsynonymous mutations. C: Estimation of mutations in $\mathrm{M}$ protein among non-synonymous mutations. D: Estimation of mutations in ORF1/ab among non-synonymous mutations. E: Estimation of mutations in ORF3a among non-synonymous mutations. F: Estimation of mutations in ORF7a among non-synonymous mutations. G: Estimation of mutations in ORF7b among nonsynonymous mutations. $\mathrm{H}$ : Estimation of mutations in ORF8a among non-synonymous mutations. I: Estimation of mutations in ORF10a among non-synonymous mutations. J: Estimation of mutations in ORF6 among non-synonymous mutations. K: Estimation of mutations in E protein among non-synonymous mutations.L: Estimation of mutations in S protein among total mutations. M: Estimation of mutations in ORF3a among total mutations. N: Estimation of mutations in NSP among total mutations. O: Estimation of mutations in N protein among total mutations. P: Estimation of mutations in $\mathrm{M}$ protein among total mutations. Q: Estimation of mutations in ORF7a among total mutations. R: Estimation of mutations in ORF7b among total mutations.

\section{Supplementary Files}

This is a list of supplementary files associated with this preprint. Click to download. 
- prismachecklist.docx

Page 18/18 